\title{
Is PMI a Leading Indicator: Case of Turkey
}

Saffet AKDA $\breve{G}$ (https://orcid.org/0000-0001-9576-6786), Department of Finance and Banking, Tarsus University, Turkey; e-mail: saffetakdag@tarsus.edu.tr

Ali DERAN (https://orcid.org/0000-0001-5377-6740), Department of Finance and Banking, Tarsus University, Turkey; e-mail: alideran@tarsus.edu.tr

Ömer ISKENDEROĞLU (https://orcid.org/0000-0002-3407-1259), Department of Business Administration, Niğde Ömer Halisdemir University, Turkey; e-mail: oiskenderoglu@ohu.edu.tr

\section{PMI Öncü Bir Gösterge mi? Türkiye Örneği}

\begin{abstract}
In this study, the causal relationships of the Purchasing Managers Index (PMI) with various financial factors are examined. As a result of the analysis, it is determined that the change in the Istanbul-Stock-Exchange-Industry Index (ISEIND) causes the change in the PMI and the changes in the PMI also causes the changes in the Industrial-Production Index (IPI) and the Capacity-UtilizationRates (CUR). It is also determined that the causality towards to PMI from the ISEIND and causality towards IPI from PMI is valid in the medium- and long-run, whereas the causality towards PMI to CUR are valid for the all periods. According to these results, PMI can be considered as a leading indicator for the real sector. However, the same result does not apply to the financial sector.

Keywords

JEL Classification Codes :

Purchasing Manager's Index, Istanbul Stock Exchange Industry Index, Industrial Production Index, Capacity Utilization Rates, Granger Casuality, Frequency Domain Causality.

Öz

$\mathrm{Bu}$ çalışmada Satınalma Yöneticileri Endeksi (PMI) ile çeşitli finansal faktörler arasındaki nedensellik ilişskisi araştırılmıştır. Analiz sonucunda BİST Sanayi Endeksindeki değişimin PMI'daki değişimin nedeni olduğu, PMI'daki değişimin ise Sanayi Üretim Endeksi (SÜE) ve Kapasite Kullanım Oranındaki (KKO) değişimin nedeni olduğu tespit edilmiştir. Ayrıca BİST Sanayi Endeksinden PMI'ya doğru nedenselliğin orta ve uzun dönemli, benzer şekilde PMI'dan SÜE doğru nedenselliğinde yine orta ve uzun dönemli olduğu, ancak PMI'dan KKO'na doğru nedenselliğin ise tüm dönemlerde geçerli olduğu tespit edilmiştir. Bu sonuçlara göre PMI'ın reel sektör için öncü bir gösterge olabileceği değerlendirilebilirken, finansal sektör için benzer bir durumun söz konusu olmadığ değerlendirilmektedir.
\end{abstract}

Anahtar Sözcükler $\quad$ : Satınalma Yöneticileri Endeksi, BİST Sanayi Endeksi, Sanayi Üretim Endeksi, Kapasite Kullanım Oranı, Granger Nedensellik, Frekans Nedensellik Analizi. 


\section{Introduction}

Investors attain many economic signals or indicators that confirm or refute their beliefs about the future of the economy. Such indicators are typically divided into three categories, namely; leading, lagging, and overlapping indicators. The PMI-Purchasing Managers' Index, which is compiled monthly by the Institute for Supply Management (ISM), is one of the most important indicators calculated since 1948 in the USA. The PMI is recognized as a sensitivity indicator since it is the result of survey data obtained from purchasing managers in many countries, particularly in the United States (Johnson \& Watson 2011:89). The Purchasing Managers' Indexes are characterized as financial indicators which have been followed by both the economics press and global markets in the measurement of economic activity conditions. Due to the fact that being one of the first official data that are reported in the relevant month by indicating the current economic activity conditions along with its correlation with the other market data, the PMI would be regarded as a crucial leading financial indicator (Istanbul Chamber of Industry, 2018). Since the purchasing managers tend to consider their financial decisions depending on economic developments, this indicator may provide advance information regarding market developments.

The Purchasing Managers' Index (PMI) is a financial indicator that identifies the tendency of businesses' purchasing managers to purchase goods and services. This indicator functions as a survey towards determining the growth estimates of enterprises. This survey, which is organized for the purchasing managers of the enterprises, includes a questionnaire about how the managers would take a position in the context of the demands of goods and services. It aims to identify the future tendencies of those managers. Those are accepted as the most observed business survey by commercial decision-makers, financial markets and central banks due to the capacity of the business world for indicating the actual monthly economic trends. At the same time, this index is recognized as one of the leading indicators of growth estimates for countries. It stems from the fact that the survey is not conducted by any governmental unit, but by business managers holding a significant share of the gross national product in the country (Istanbul Chamber of Industry, 2018).

The PMI, calculated by Markit Economics, is published in monthly reports for various sectors in many developed and developing countries. As a general rule, PMI is published on the first business day of each month. The relevant index is a composite index calculated by five different indicators such as new orders, production, employment, the delivery time of suppliers and input stock. The survey questionnaire for the calculation of the indexes is prepared for determining how the parameters of those five different indicators are expected to be developed from the previous period to the next period. Spillover indexes are calculated for each parameter, and the PMI is calculated using these spillover indexes (Istanbul Chamber of Industry, 2018).

Similarly, there is a real sector confidence index published by the Central Bank of the Republic of Turkey (CBRT). The real sector confidence index is calculated separately for the current situation on the basis of the components, the total order quantity and the inventory amount of manufactured goods, the production volume for the next three months, 
total employment, total order quantity, and export order, fixed capital investment expenditure, and general conduct. The real sector confidence index differs from the PMI since it also includes confidence-based forecasted information for the upcoming period. In addition, the CBRT also publishes services and construction sector confidence indexes. Upon considering regarding scope, the PMI indicates the attitudes of purchasing managers, whereas real sector confidence reflects the tendencies of business owners or senior executives operating in the manufacturing industry.

The PMI can be used as a signal for the future since it includes the attitude of the purchasing managers towards economic improvements. The relevant index which is above 50 indicates an improvement in comparison with the previous month, whereas the index which is below 50 indicates a deterioration in comparison with the previous month. The PMI is seen as an important tendency indicator in terms of indicating the direction of change rather than the quantitative size of the change in the operating conditions of the underlying economy or sectors (Istanbul Chamber of Industry, 2018). Accordingly, this study aims to determine whether or not PMI is a leading indicator. For this purpose, the causal relationship between the PMI and Istanbul Stock Exchange (ISE) Industry Index, the Industrial Production Index and the Capacity Utilization Rate were tested. In this respect, the study consists of five parts. In the first part, information is provided about the PMI and its scope. In the second part, the studies investigating various other factors that interact with the PMI are summarized. In the third part, information is given about the method used in the study. In the fourth part, the obtained findings of the study are included. In the last part, the findings are interpreted, and various suggestions are presented.

\section{Literature Review}

Only a limited number of studies which examined the interaction between the Purchasing Managers' Index (PMI) and various financial indicators are found during the literature review. Accordingly, the studies which examined the relationship between the PMI and various financial indicators are summarized in Table 1.

Table: 1

\section{Studies Conducted on the Subject}

\begin{tabular}{|l|l|l|l|}
\hline Studies & Model & Data & Results \\
\hline Afshar et al., (2007) & Granger Causality & 1980: Q1 - 2005: Q4 & PMI Granger-causes economic growth. \\
\hline Chindamo (2010) & Granger Causality & 1993: Q3 - 2010: Q2 & $\begin{array}{l}\text { A causality from the PMI towards the Manufacturing Industry growth } \\
\text { is detected. }\end{array}$ \\
\hline $\begin{array}{l}\text { Johnson \& Watson } \\
(2011)\end{array}$ & Regression Analysis & $\begin{array}{l}\text { January 1973 - } \\
\text { December 2009 } \\
\text { Monthly Data }\end{array}$ & $\begin{array}{l}\text { A positive and significant relationship between the PMI and stock } \\
\text { returns is detected. }\end{array}$ \\
\hline Joseph et al. (2011) & Neural Network Models & $\begin{array}{l}\text { August 1964 - July } \\
\text { 2010 Monthly Data }\end{array}$ & $\begin{array}{l}\text { Compressed interest rates are detected as one of the determinants of } \\
\text { the PMI. }\end{array}$ \\
\hline Tsuchiya (2012) & $\begin{array}{l}\text { Fisher's Exact Test based } \\
\text { on Probability Table }\end{array}$ & $\begin{array}{l}\text { January 1991 - } \\
\text { December 2010 } \\
\text { Monthly Data }\end{array}$ & $\begin{array}{l}\text { The PMI is determined as a useful predictor of the direction of change } \\
\text { in Industrial Production Index. However it does not succeed in } \\
\text { predicting the GDP. }\end{array}$ \\
\hline $\begin{array}{l}\text { Khundrakpam \& } \\
\text { George (2013) }\end{array}$ & $\begin{array}{l}\text { Regression and } \\
\text { Cointegration }\end{array}$ & $\begin{array}{l}\text { April 2005 - October } \\
\text { 2012 Monthly Data }\end{array}$ & $\begin{array}{l}\text { The PMI is determined as a useful indicator for the purpose of } \\
\text { forecasting WPI. }\end{array}$ \\
\hline Chiang (2014) & Granger Causality & $\begin{array}{l}\text { January 1997 - } \\
\text { December 2014 } \\
\text { Monthly Data }\end{array}$ & $\begin{array}{l}\text { The PMI Granger-causes Vanguard Total Stock Market ETF (VTI), } \\
\text { whereas VTI Granger-causes PMI. }\end{array}$ \\
\hline Mudgal (2014) & Granger Causality & $\begin{array}{l}\text { August 2000 - August } \\
\text { 2013 Monthly Data }\end{array}$ & $\begin{array}{l}\text { A causal relationship is determined from the stock prices of } \\
\text { manufacturing sector companies towards the PMI. }\end{array}$ \\
\hline
\end{tabular}




\section{Data and Methodology}

In this study, the Purchasing Managers' Index (PMI), ISE Industry Index, the Industrial Production Index and the Manufacturing Industry Capacity Utilization Rate are utilized by calculating the percentage change in monthly frequency over the period from February 2007 to December 2017. The main reason for determining the period interval involves the first publication of PMI data as of February 2007. The data of the PMI, ISE Industrial Index, the Industrial Production Index and the Capacity Utilization Rate are obtained from IHS Markit authorized by Istanbul Chamber of Industry, ISE, Turkish Statistical Institute (TSI), and the CBRT's website, respectively.

In order to test the causal relationship, the data are subjected to unit root tests with the Augmented Dickey-Fuller (ADF), Philips and Perron test to determine whether the series is stationary. In order to determine whether there is causality between the variables after determining that the data is stationary, Granger (1969) causality test and Breitung and Candelon (2006) frequency causality test are applied to determine whether the causality between variables is short, medium and long term.

Yule (1926) drew attention to stationarity of time-series in analyses conducted with macroeconomic data. Similarly, Nelson and Plosser (1982) stated that the time-series must be stationary in order to be used in statistical analysis. Stationarity can be expressed as the mean and variance of time series being independent of time. Stationarity is commonly tested by Philips and Perron, Dickey-Fuller and Augmented Dickey-Fuller (ADF) tests (Saraç et al., 2016). Related unit root tests, assumptions, hypotheses, and the results may differ depending on the sample size. For instance, results in the ADF test may vary depending on the statistical confidence level, lag length and sample size (Campbell \& Perron, 1991). Balke and Fomby (1997) and Schwert (2002) stated that the Philips and Perron test with larger sample sized series provided more accurate results.

Granger Causality Test is based on the principle of testing whether there is a unilateral or bilateral causality relationship between the two variables. In Granger (1969), causality is expressed as the measurement of the use of the past values of $\mathrm{X}$ for the estimation of $\mathrm{Y}$ in comparison with the non-use of the past values of X. According to Granger (1988), it can be concluded that $\mathrm{X}$ Granger-causes $\mathrm{Y}$ if the use of past values makes the prediction more successful. Measurements in the relevant test are performed with $\mathrm{F}$ and Wald tests. In this context, it can be concluded that X Granger-causes Y, or vice versa, as well as bilateral causality between $\mathrm{X}$ and $\mathrm{Y}$, or no causality at all. Although the Granger Causality test points out some results regarding the causality between series, the Wald and $\mathrm{F}$ tests used in the methodology may reveal a long-run relationship, whereas the short-term relationships may be ignored (İskenderoğlu \& Akdağ, 2017). In order to solve this problem, Geweke (1982), Hosoya (1991) and Yao and Hosoya (2000) proposed the measurement of causality for frequencies based on the decomposition of spectral density functions. Frequency domain causality is preferred since it allows Granger causality to be evaluated at different frequencies and is an easily applicable model because of being based on linear constraints 
(Yanfeng, 2012:58). The spectral density function, which is the basis of frequency domain causality, can be expressed by the following equation (Kratschell \& Schmidt, 2012):

$$
f_{x}(\omega)=\frac{1}{2 \pi}\left\{\left|\Psi_{11}\left(e^{-i \omega}\right)\right|^{2}+\left|\Psi_{12}\left(e^{-i \omega}\right)\right|^{2}\right\}
$$

However, the problem of the use of the F-test in the implementation of the relevant tests is solved by the application of the proposed linear limitations in the Breitung and Candelon (2006). Granger Causality Test examines a single test statistic for the variables included in the analysis, whereas a nonlinear causality analysis is performed by Frequency Causality Test. Granger causality at different frequencies by Geweke (1982) and Hosoya (1991) is expressed in the following equation:

$$
M_{y \rightarrow x}(\omega)=\log \left[\frac{2 \pi f_{x}(\omega)}{\left|\Psi_{11}\left(e^{-i \omega}\right)\right|^{2}}\right]=\log \left[1+\frac{\left|\Psi_{12}\left(e^{-i \omega}\right)\right|^{2}}{\left|\Psi_{11}\left(e^{-i \omega}\right)\right|^{2}}\right]
$$

According to Equation (2) above, if $\left|\Psi_{12}\left(e^{-i \omega}\right)\right|=0$, there would not be a causality from y variable to $\mathrm{x}$ variable at any $\omega$ frequency (Ciner, 2011, 500). Breitung and Candelon (2006) recommended a new method to test the null hypothesis suggesting no causality.

If $M_{y \rightarrow x}(\omega)=0,\left|\Psi_{12}\left(e^{-i \omega}\right)\right|=0$, then the equation below is used:

$$
\Psi(L)=\Theta(L)^{-1} G^{-1} \text { and } \Psi_{12}(L)=-\frac{g^{22} \Theta_{12}(L)}{|\Theta(L)|}
$$

$g^{22}$ denotes the lower diagonal element of $G^{-1}$ matrix, whereas $|\Theta(L)|$ stands for the determinant of $\Theta(L)$. Thus, the hypothesis suggesting that " $y$ " does not cause " $x$ " at frequency " $\omega$ " can be tested by courtesy of the following equation (Bodart \& Candelon, 2009):

$$
\left|\Theta_{12}\left(e^{-i \omega}\right)\right|=\left|\sum_{k=1}^{p} \Theta_{12, k} \cos (k \omega)-\sum_{k=1}^{p} \Theta_{12, k} \sin (k \omega) i\right|=0
$$

$\left|\Theta_{12}\left(e^{-i \omega}\right)\right|=0$ is the sufficient condition corresponding to the case where " $y$ "" does not cause " $x$ " at frequency " $\omega$ " (Tar1 et al., 2012). The model brought forth by Breitung ve Candelon (2006) is based on the following linear restrictions:

$$
\begin{aligned}
& \sum_{k=1}^{p} \Theta_{12, k} \cos (k \omega)=0 \\
& \sum_{k=1}^{p} \Theta_{12, k} \sin (\mathrm{k} \omega)=0
\end{aligned}
$$

Upon simplification of the notations under these linear restrictions; $\alpha_{j}=\Theta_{11, j}$ and $\beta_{j}=\Theta_{12, j}$, so that the VAR equation for $x_{t}$ can be written as follows:

$$
x_{t}=\alpha_{1} x_{t-1}+\cdots+\alpha_{p} x_{t-p}+\beta_{1} y_{t-1}+\cdots+\beta_{p} y_{t-p}+\varepsilon_{1 t}
$$


Since the hypothesis $M_{y \rightarrow x}(\omega)=0$ is equivalent to the linear restrictions, $\mathrm{H}_{0}$ can be written as follows:

$\mathrm{H}_{0}: R(\omega) \beta=0 \quad\left(\beta=\left[\beta_{1}, \ldots, \beta_{p}\right]^{\prime}\right)$ whereas $R(\omega)$ can be estimated with the following equation:

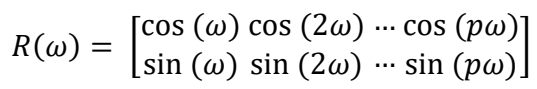

Since the test method has (2, T-2p) degree of freedom and F-distribution for $\omega \in$ $(0, \pi)$, the causality can be tested by standard F-test for $\mathrm{H}_{0}: R(\omega) \beta=0$.

\section{Findings}

In this study that analyzed the causality between the Purchasing Managers' Index (PMI), ISE Industry Index (ISEIND), the Industrial Production Index (IPI) and the Capacity Utilization Rate (CUR), the analysis period is determined as for February 2007 - December 2017. Descriptive statistics on variables are presented in Table 2.

Table: 2

\section{Descriptive Statistics}

\begin{tabular}{|c|c|c|c|c|}
\hline Variables & Mean & Minimum & Maximum & Standard Deviation \\
\hline PMI & 0,0002 & $-0,1512$ & 0,1814 & 0,0411 \\
\hline ISEIND & 0,0128 & $-0,1959$ & 0,1581 & 0,0662 \\
\hline IPI & 0,0044 & $-0,0678$ & 0,0667 & 0,0223 \\
\hline CUR & 0,0001 & $-0,0761$ & 0,0562 & 0,0155 \\
\hline
\end{tabular}

Upon examining Table 2, the highest volatility among the series is seen in ISE Industry Index.

In addition, the highest value belongs to the PMI. The unit root test results of the relevant variables can be seen in Table 3 .

Table: 3

\section{Unit Root Test Results}

\begin{tabular}{|c|c|c|c|c|c|}
\hline \multirow{2}{*}{ Variables } & \multirow{2}{*}{ Test Type } & \multicolumn{2}{|c|}{$\mathrm{ADF}$} & \multicolumn{2}{|c|}{ PP } \\
\hline & & Test Stat. & Probability & Test Stat. & Probability \\
\hline \multirow{2}{*}{ PMI } & Constant & $-7,2303$ & 0,0000 & $-7,1385$ & 0,0000 \\
\hline & Constant and Trend & $-7,1992$ & 0,0000 & $-7,1084$ & 0,0000 \\
\hline \multirow{2}{*}{ ISEIND } & Constant & $-9,8098$ & 0,0000 & $-9,8422$ & 0,0000 \\
\hline & Constant and Trend & $-9,8028$ & 0,0000 & $-9,8011$ & 0,0000 \\
\hline \multirow{2}{*}{ IPI } & Constant & $\begin{array}{l}-14,0749 \\
\end{array}$ & 0,0000 & $-13,7805$ & 0,0000 \\
\hline & Constant and Trend & $-14,1645$ & 0,0000 & $-13,8673$ & 0,0000 \\
\hline \multirow{2}{*}{ CUR } & Constant & $-9,4922$ & 0,0000 & $-9,7779$ & 0,0000 \\
\hline & Constant and Trend & $-9,5330$ & 0,0000 & $-9,7940$ & 0,0000 \\
\hline
\end{tabular}

* The lag length is determined according to Akaike Information Criterion.

The results in Table 3 indicate the stationarity of the PMI, ISE Industrial Index, the Industrial Production Index and the Capacity Utilization Rate series at $1 \%$ level. Moreover, these results indicate that all series have mean-reverting tendencies, but Granger (1969) 
stated that causality analysis could also be performed. The results of the Granger (1969) causality analysis, which examines the causality relationship between the series as one of the main causality analyses, can be examined in Table 4.

Table: 4

Granger (1969) Causality Results

\begin{tabular}{|c|c|c|c|c|}
\hline Direction of Causality & Null Hypothesis & F Stat. & Lag & Result \\
\hline PMI $\rightarrow$ ISEIND & PMI does not Granger-cause ISEIND & $1,6389(0,1553)$ & 5 & No Granger causality. \\
\hline ISEIND $\rightarrow$ PMI & ISEIND does not Granger-cause PMI & $3,5597(0,0050)^{*}$ & 5 & Granger causality exists. \\
\hline PMI $\rightarrow$ IPI & PMI does not Granger-cause IPI & $9,1513(0,0000)^{*}$ & 6 & Granger causality exists. \\
\hline IPI $\rightarrow$ PMI & IPI does not Granger-cause PMI & $0,9592(0,4563)$ & 6 & No Granger causality. \\
\hline PMI $\rightarrow$ CUR & PMI does not Granger-cause CUR & $7,7129(0,0000)^{*}$ & 5 & Granger causality exists. \\
\hline CUR $\rightarrow$ PMI & CUR does not Granger-cause PMI & $1,5937(0,1674)$ & 5 & No Granger causality. \\
\hline
\end{tabular}

The lag length is determined according to the Akaike Information Criterion.Probability values are indicated in parentheses.

* indicates significance at $1 \%$ level of significance.

The results in Table 4 indicate the existence of a unilateral causality from ISE Industry Index towards the PMI, however no causality from the PMI towards ISE Industry Index. A unilateral causality relationship from the PMI towards the Industrial Production Index is also determined. Nonetheless, a unilateral causality relationship from the PMI towards the Capacity Utilization Rate is also found. The complex causality behavior of PMI and other variables need more sophisticated tests to have further view.

The Granger (1969) causality test and the Breitung and Candelon (2006) frequency domain causality test use the same lag lengths regardless of having different assumptions. In this respect, Granger (1969) found a single causality result for the entire analysis period, whereas Breitung and Candelon (2006) yielded different results in the short-, medium- and long-run through the unit circle. Accordingly, it would be stated that the Breitung and Candelon (2006) frequency domain causality test reveals more detailed results depending on the frequency (İskenderoğlu \& Akdağ, 2017: 631).

In the Breitung and Candelon (2006) frequency domain causality test, the period lengths are calculated based on the $2 \pi / f_{x}(\omega)$ the formula, which represents the perimeter of the unit circle. In this context, term lengths correspond to 13 - 63 months interval in the long-run, 4 - 13 months interval in the medium-run and 2 - 3 months interval in the shortrun. Breitung and Candelon (2006) Frequency domain causality test results can be examined in Table 5. 


\section{Table: 5}

\section{Frequency Domain Causality Results}

\begin{tabular}{|c|c|c|c|c|c|c|}
\hline \multirow{2}{*}{ Variables } & \multicolumn{2}{|c|}{ Long-Term } & \multicolumn{2}{|c|}{ Medium-Term } & \multicolumn{2}{|c|}{ Short-Term } \\
\hline & $\mathrm{w}=0.1$ & $\mathrm{w}=0.5$ & $\mathrm{w}=1.0$ & $\mathrm{w}=1.5$ & $\mathrm{w}=2.0$ & $\mathrm{w}=2.5$ \\
\hline PMI $\rightarrow$ ISEIND & $\begin{array}{c}3.8540 \\
(0,1455)\end{array}$ & $\begin{array}{c}5,5533 \\
(0,0622)\end{array}$ & $\begin{array}{c}4,4902 \\
(0,1059)\end{array}$ & $\begin{array}{c}0,6562 \\
(0,7202)\end{array}$ & $\begin{array}{c}0,1359 \\
(0,9343)\end{array}$ & $\begin{array}{c}1,5388 \\
(0,4632)\end{array}$ \\
\hline ISEIND $\rightarrow$ PMI & $\begin{array}{c}15,2744 \\
(0,0005)^{*}\end{array}$ & $\begin{array}{c}14,8016 \\
(0,0006)^{*}\end{array}$ & $\begin{array}{c}12,7826 \\
(0,0017) *\end{array}$ & $\begin{array}{c}6,1330 \\
(0,0466)^{* *}\end{array}$ & $\begin{array}{c}0,2672 \\
(0,8749)\end{array}$ & $\begin{array}{c}4,4812 \\
(0,1063)\end{array}$ \\
\hline $\mathrm{PMI} \rightarrow \mathrm{IPI}$ & $\begin{array}{c}42,9700 \\
(0,0000)^{*}\end{array}$ & $\begin{array}{c}28,3813 \\
(0,0000)^{*}\end{array}$ & $\begin{array}{c}26,7798 \\
(0,0000)^{*}\end{array}$ & $\begin{array}{c}18,6473 \\
(0,0001)^{*}\end{array}$ & $\begin{array}{c}5,3419 \\
(0,0692)\end{array}$ & $\begin{array}{c}5,5938 \\
(0,0610)\end{array}$ \\
\hline IPI $\rightarrow$ PMI & $\begin{array}{c}0,8642 \\
(0,6491)\end{array}$ & $\begin{array}{c}1,3292 \\
(0,5144)\end{array}$ & $\begin{array}{c}2,1708 \\
(0,3377)\end{array}$ & $\begin{array}{c}3,1437 \\
(0,2077)\end{array}$ & $\begin{array}{c}4,2122 \\
(0,1217)\end{array}$ & $\begin{array}{c}0,8750 \\
(0,6456)\end{array}$ \\
\hline $\mathrm{PMI} \rightarrow \mathrm{CUR}$ & $\begin{array}{c}34,4061 \\
(0,0000)^{*}\end{array}$ & $\begin{array}{c}30,2252 \\
(0,0000)^{*}\end{array}$ & $\begin{array}{c}19,6646 \\
(0,0000)^{*}\end{array}$ & $\begin{array}{c}6,4026 \\
(0,0407) * *\end{array}$ & $\begin{array}{c}7,0718 \\
(0,0291)^{* * *}\end{array}$ & $\begin{array}{c}9,8311 \\
(0,0073)^{*}\end{array}$ \\
\hline $\mathrm{CUR} \rightarrow \mathrm{PMI}$ & $\begin{array}{c}7,2923 \\
(0,0261)^{* *}\end{array}$ & $\begin{array}{c}6,4857 \\
(0,0391)^{* *}\end{array}$ & $\begin{array}{c}3,1413 \\
(0,2079)\end{array}$ & $\begin{array}{c}1,1430 \\
(0,5646)\end{array}$ & $\begin{array}{c}0,9191 \\
(0,6315)\end{array}$ & $\begin{array}{c}2,2941 \\
(0,3176)\end{array}$ \\
\hline
\end{tabular}

The lag length is determined according to the Akaike Information Criterion. Probability values are indicated in parentheses.

* indicates significance at $1 \%$ level of significance.

** indicates significance at $5 \%$ level of significance.

Upon examining Table 5 which indicates the frequency domain causality results, no causality relationship running from the PMI towards ISE Industry Index is detected. However, the causality relationships from ISE Industry Index towards the PMI are determined in the medium- and long-run. In addition, the existence of causality relationships from the PMI towards the Industrial Production Index in the medium- and long-run, and towards the Capacity Utilization Rate in the short-, medium- and long-run is detected. A causality relationship from the Capacity Utilization Ratio towards the PMI is detected only in the long-run. Nonetheless, no causality relationship from the Industrial Production Index towards the PMI is detected during any period.

The results from a finance perspective indicate that investors do not credit PMI on investing decisions. However, purchase managers are monitoring ISE industry index to assess the advantages and disadvantages of purchasement. This result reveals that ISE industry index is a motivating parameter for purchase managers. Besides, the same motivating conditions for PMI are also found to be efficient on IPI.

The results of lags at different frequencies can be examined with the graphs in Appendix 1.

\section{Conclusion}

The Purchasing Managers' Index (PMI) is an important index that measures the attitudes of purchasing managers and is calculated over the period from 2007 onwards. This index is used as an important indicator for central banks, investors and sector managers. In this study, it is examined to determine whether or not causality relationships exist between the PMI and ISE Industry Index, Industrial Production Index and Capacity Utilization Rate via Granger (1969) and Breitung and Candelon (2006) causality tests. The results of the analysis conducted over the period from February 2007 to December 2017 indicate that the PMI unilaterally causes the Industrial Production Index in the medium- and long-run. Such 
a unilateral relationship between the PMI and the Industrial Production Index is similar to the result of Tsuchiya (2012).

Moreover, it is concluded that PMI is the cause of the Capacity Utilization Rate in the short-, medium- and long-run, whereas the Capacity Utilization Rate causes the PMI only in the long-run. Nevertheless, ISE Industry Index is determined to unilaterally cause the PMI in the medium- and long-run. Such unilateral relationship, which is determined between the PMI and ISE Industry Index, shares similarities with of Mudgal (2014), but it is distinguished from the related study by mutual causality determined in Chiang (2014). From a more detailed perspective, if PMI is determined as a proxy for real sector activity and ISE Industry Index is determined as a proxy for financial sector activity, the result of no causal relationship running from the PMI towards ISE Industry Index can be interpreted as real sector activity does not causally affect financial sector activity. According to these results, PMI can be considered as a leading indicator for the real sector. However, the same result does not apply to the financial sector.

According to the results obtained from the study, it can also be stated that the course of the stock market index is one of the determining factors that affect the purchasing managers' future decisions. Furthermore, it also suggests that the PMI can be used to estimate the Industrial Production Index and the Capacity Utilization Rate. It is thought that new studies, upon examining the relationships between the PMI and other different financial data, would provide distinctive contributions to the subject.

\section{References}

Afshar, T. \& G. Arabian \& R. Zomorrodian (2007), "Stock Return, Consumer Confidence, Purchasing Manager's Index and Economic Fluctuations", Journal of Business and Economics Research, 5(8), 97-106.

Balke, N.S. \& T.B. Fomby (1997), “Threshold Cointegration”, International Economic Review, $38(3), 627-645$.

Bodart, V. \& B. Candelon (2009), "Evidence of Interdependence and Contagion Using a Frequency Domain Framework", Emerging Markets Review, 10(2), 140-150.

Borsa İstanbul (2018), <http://www.borsaistanbul.com>, 01.06.2018.

Breitung, J. \& B. Candelon (2006), "Testing for Short and Long-Run Causality: A Frequency Domain Approach", Journal of Econometrics, 132(2), 363-378.

Campbell, J.C. \& P. Perron (1991), "Pitfall and Opportunities: What Macroeconomists should Know About Unit Roots", NBER Technical Working Paper, <http://www.journals.uchicago.edu/doi/pdfplus/10.1086/654163>, 07.06.2018.

Central Bank of the Republic of Turkey (2018), <http://www.tcmb.gov.tr>, 15.06.2018.

Chiang, C.C. (2014), "A Study on the Relationships between Modified Purchase Management Index and Vanguard ETF", Master Thesis, Tayvan: National Sun Yat-sen University.

Chindamo, P. (2010), “The Predictive Ability of Business Survey Indices”, Economic Papers, 29(4), 466-482.

Ciner, Ç. (2011) "Eurocurrency Interest Rate Linkages: A Frequency Domain Analysis", International Review of Economics and Finance, 20(4), 498-505. 
Geweke, J. (1982), "Measurement of Linear Dependence and Feedback between Multiple Time Series", Journal of the American Statistical Association, 77(378), 304-313.

Granger, C.W.J. (1969), "Investigating Causal Relations by Econometric Models and Cross-Spectral Methods". Econometrica, 37(3), 424-438.

Granger, C.W.J. (1988), "Some Recent Development in a Concept of Causality", Journal of Econometrics, 39(1-2), 199-211.

Hosoya, Y. (1991), “The Decomposition and Measurement of the Interdependency between SecondOrder Stationary Processes", Probability Theory Relat Fields, 88(4), 429-444.

Istanbul Chamber of Industry (2018), <http://www.iso.org.tr>, 15.06.2018.

İskenderoğlu, Ö. \& S. Akdağ (2017), "Finansal Hizmetler Güven Endeksinin Geçerliliğinin İncelenmesi: Türkiye Örneği”, Uluslararası Ekonomik Araştırmalar Dergisi, 3(4), 625633.

Johnson, M.A. \& K.J. Watson (2011), “Can Changes in the Purchasing Managers' Index Foretell Stock Returns? An Additional Forward-Looking Sentiment Indicator", The Journal of Investing, 20(4), 89-98.

Joseph, A. \& M. Larrain \& C. Turnerc (2011), "Forecasting Purchasing Managers' Index with Compressed Interest Rates and Past Values", Procedia Computer Science, 6, 213-218.

Khundrakpam, J.K. \& A.T. George (2013), “An Empirical Analysis of the Relationship Between WPI and PMI-Manufacturing Price Indices in India. Reserve Bank of India", RBI Working Paper Series, 6, 1-15.

Kratschell, K. \& T. Schmidt (2012), "Long-Run Trends or Short-Run Fluctuations - What Establishes the Correlation Between Oil and Food Prices?", Ruhr Economic Paper, 357, 3-19.

Mudgal, N. (2014), “An Empirical Analysis of The Relationship Between the Purchasing Managers' Index (PMI) and Share Prices in the Manufacturing Sector of South Africa", Master Thesis, Faculty of Commerce, Law, and Management, Johannesburg, University of the Witwatersrand.

Nelson, C.R. \& C.R. Plosser (1982), "Trends and Random Walks in Macroeconomic Time Series: Some Evidence and Implications", Journal of Monetary Economics, 10(2), 139-162.

Saraç, T.B. \& Ö. İskenderoğlu \& S. Akdağ (2016), "Yerli ve Yabanc1 Yatırımcılara ait Risk İştahlarının İncelenmesi: Türkiye Örneği”, Sosyoekonomi, 24(30), 29-44.

Schwert, G.W. (2002), “Tests for Unit Roots: A Monte Carlo Investigation”, Journal of Business and Economic Statistics, 20(1), 5-17.

Tarı, R. \& T. Abasız \& F. Pehlivanoğlu (2012), “TEFE (ÜFE) - TÜFE Fiyat Endeksleri Arasındaki Nedensellik Ilişkisi: Frekans Alanı Yaklaşımı”, Akdeniz I.I. B.F. Dergisi, 24, 1- 15.

Tsuchiya, Y. (2012), “Is the Purchasing Managers' Index Useful for Assessing the Economy's Strength? A Directional Analysis", Economics Bulletin, 32(2), 1302-1311.

Turkish Statistical Institute (2018), <http://www.tuik.gov.tr>, 15.06.2018.

Yanfeng, W. (2013), “The Dynamic Relationships Between Oil Prices and The Japanese Economy: A Frequency Domain Analysis", Review of Economics and Finance, 3, 57-67.

Yao, F. \& Y. Hosoya (2000), "Inference on One-Way Effect and Evidence in Japanese Macroeconomic Data", Journal of Econometrics, 98(2), 225-255. 
Yule, G.U. (1926), "Why Do We Sometimes Get Nonsense-Correlations Between Time-Series? A Study in Sampling and the Nature of Time-Series", Journal of the Royal Statistical

Society, 89(1), 1-63.

\section{Appendix: 1}

\section{Graphics of the Frequency Domain Causality Analysis}

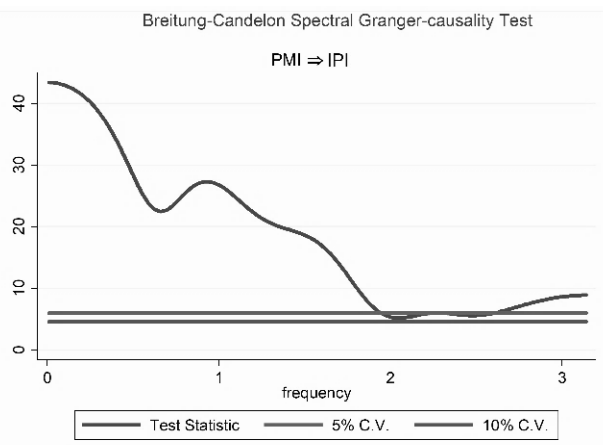

Breitung-Candelon Spectral Granger-causality Test

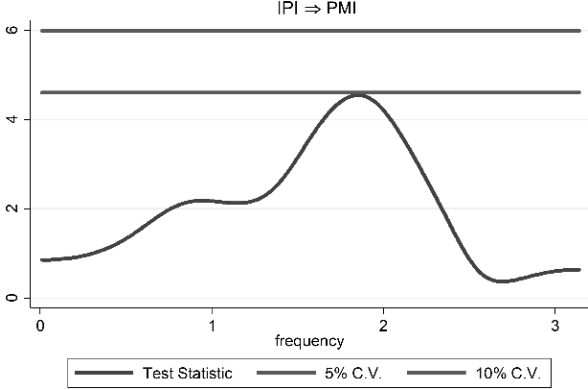

Breitung-Candelon Spectral Granger-causality Test ISEIND $\Rightarrow \mathrm{PM}$

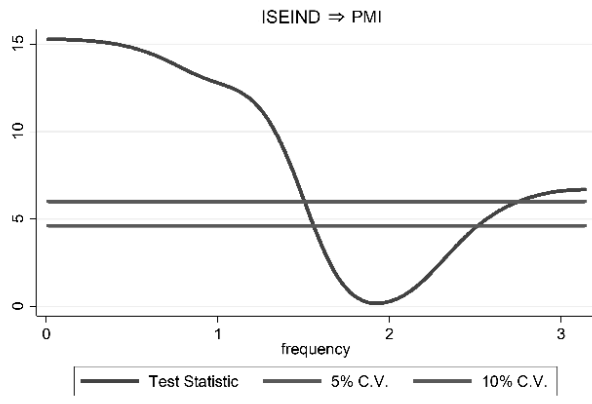

Breitung-Candelon Spectral Granger-causality Test

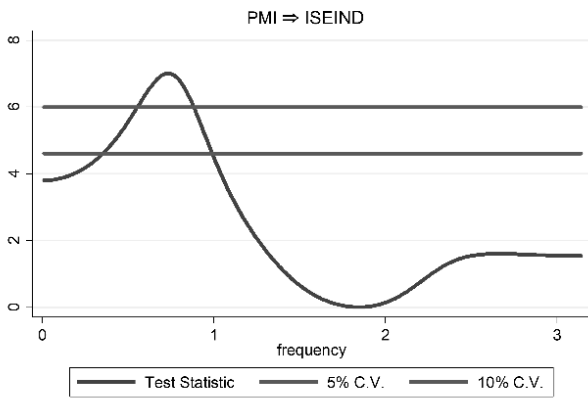

Breitung-Candelon Spectral Granger-causality Test $\mathrm{PMI} \Rightarrow \mathrm{CUR}$

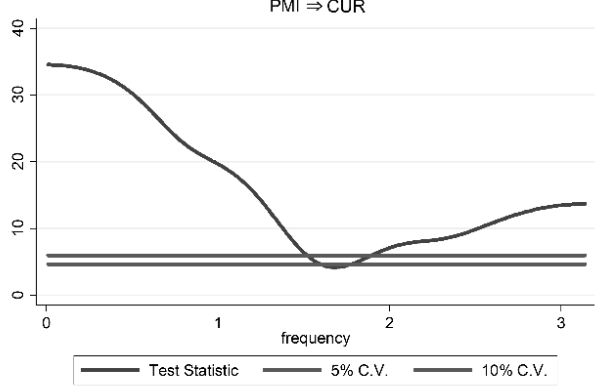

Breitung-Candelon Spectral Granger-causality Test $\mathrm{CUR} \Rightarrow \mathrm{PMI}$

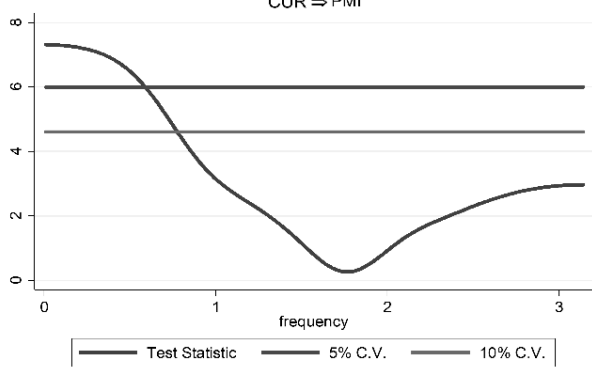


Akdağ, S. \& A. Deran \& Ö. İskenderoğlu (2020), "Is PMI a Leading Indicator: Case of Turkey”, Sosyoekonomi, Vol. 28(45), 37-47. 